\title{
Pregnancy with uterine prolapse: Duhrssen's incision still valid in today's scenario?
}

\section{Kiran Pandey*, Sangeeta Arya, Shefali Pande}

Department of Obstetrics \& Gynaecology, G.S.V.M. Medical College, Kanpur, Uttar Pradesh, India

Received: 28 September 2013

Accepted: 8 October 2013

*Correspondence:

Dr. Kiran Pandey,

E-mail: dr.kiranpandey@gmail.com

(C) 2013 Pandey K et al. This is an open-access article distributed under the terms of the Creative Commons Attribution Non-Commercial License, which permits unrestricted non-commercial use, distribution, and reproduction in any medium, provided the original work is properly cited.

\begin{abstract}
Background: To study uterine prolapse during pregnancy and its effect on perinatal outcome; importance of Duhrssen incision in aiding vaginal delivery in prolapse.

Methods: A retrospective study conducted by reviewing 49 antenatal women with uterine prolapse admitted in the labour room of Department of Obs. \& Gynae at G.S.V.M. Medical College, Kanpur over a period of 3 years (201013).

Results: $17(35.4 \%)$ women were booked. $25 \%$ of booked antenatal women presenting to our hospital with preterm labour pains managed conservatively. Incidence of preterm labour and delivery, application of Duhrssen's incision in aiding vaginal delivery and h/o difficult delivery was statistically significant in unbooked women.

Conclusion: Preterm labour associated with prolapse led to significant perinatal morbidity and mortality. Management of uterine prolapse during labour is individualized depending on the severity of prolapse, gestational age, parity and women's preference.
\end{abstract}

Keywords: Prolapse, Pregnancy, Uterine

\section{INTRODUCTION}

Uterine prolapse is a common gynecologic condition but is uncommon during pregnancy. The overall incidence of cervical prolapse in pregnancy is 1 case per 10,000 to 15,000 deliveries $^{1,2}$ in other countries but in India it is as high as 1 per 547 deliveries. $^{3}$ This is due to one-fourth deliveries being conducted by untrained birth attendants. The trend of bearing more than two children further increases the risk of prolapse due to malnutrition, decreased interval in between consecutive pregnancies and repeated wear and tears on supports of the uterus. Pregnancy with uterine prolapse categorizes the woman as high risk due to associatedcomplications like abortion, associated urinary tract infection and acute retention, preterm labor., ${ }^{4,5}$

Cervical dessication and edema, ulceration leads to complications during labour like cervical dystocia, non progression of labour, obstructed labour eventually leading to uterine rupture or damage. Duhrssen's incision becomes a handy tool for obstetrician in distress in such circumstances.

Duhrssen's incisions are 3 surgical incisions of an incompletely dilated cervix, corresponding roughly to 2,6 and 10 o'clock position used as a means of effecting immediate delivery of the fetus when there is an entrapped head. In some studies (Daskalakis G, et al) elective caesarean section near term is advocated to prevent further pelvic floor damage.

A rising tendency to neglect obstetric manoeuvres and opting for caesarean section as an easy way to avoid obstetric complications is being observed among the younger obstetricians. Keeping this in view, we implemented Duhrssen's incisions as an effective tool to minimize obstetric complications in pregnancy with prolapse during labour. 
Duhrssen's incisions are one of such procedures which have proved quite useful.

\section{METHODS}

This retrospective study was conducted by reviewing 49 antenatal women with uterine prolapse (cervical descent outside the introitus) admitted in the labor room of Department of Obs. \& Gynae at G.S.V.M. Medical College, Kanpur over a period of 3 years (2010-13). Sixteen women who presented to us in first or second trimester, were managed by bed rest in slight Trendelenberg position with acriflavine glycerine packing done until the cervix became soft and the prolapse could be reposited back. Then ring pessary was inserted to retain the cervix in normal position and were discharged with regular follow-up. The other thirty-two women were unbooked and had came in emergency in labor. The maternal and fetal parameters were observed. Data collected in the study were analysed and $p$ value $<0.05$ is considered statistically significant.

\section{RESULTS}

$17(35.4 \%)$ women were booked. $25 \%$ of booked antenatal women who presented to our hospital at $<37$ weeks with preterm labour pains were managed conservatively. They were discharged and advised to come for follow-up every 2 weeks (Table 1 ).
$18.8 \%$ (3) of booked women at term had to be taken for emergency LSCS,1(16.7\%) for intractable bleeding per vaginum, 2(66.7\%) for fetal distress . In booked women, complications like cervical dessication and edema present in $11.76 \%$ women, premature rupture of membranes in $5.9 \%$, preterm labour in $2(12.5 \%)$ women.

Regarding perinatal outcome, there were 2 NICU admissions (11.8\%).(Table II). As regards past obstetric history, there was $\mathrm{H} / \mathrm{O}$ prolonged labour in 15(93.8\%) booked women, $\mathrm{H} / \mathrm{O}$ difficult delivery in $1(6.2 \%)$ woman.

$66.6 \%$ of women were unbooked and admitted in emergency.

$29(90.6 \%)$ of unbooked women delivered normally, $27(93.1 \%)$ women with the aid of Duhrssen's incision, whereas $3(9.4 \%)$ had to be taken for emergency LSCS (indication: fetal distress).

Cervical dessication and edema present in 2(11.8\%) women, premature rupture of membranes in $1(5.9 \%)$, preterm labour in $32(100 \%)$ cases.

Post partum complications like PPH occurred in 2(6.3\%) cases (Table 1).

Table 1: Mode of delivery, antenatal and postnatal complications.

\begin{tabular}{|c|c|c|c|c|c|c|}
\hline S. No & & $\begin{array}{l}\text { Booked } \\
(n=16)\end{array}$ & Percentage & $\begin{array}{l}\text { Unbooked } \\
(n=32)\end{array}$ & Percentage & P value \\
\hline 1 & Mode of Delivery & & & & & \multirow{3}{*}{$\begin{array}{l}\text { On applying } \\
\text { Mann-Whitney U } \\
\text { test } \mathrm{Z} \text { is } 0.916 \text { and } \\
\text { Asymptotic Sig is } \\
\mathrm{P}>0.05\end{array}$} \\
\hline $1 \mathrm{a}$ & $\begin{array}{l}\text { Normal Vaginal } \\
\text { Delivery }\end{array}$ & 13 & 81.2 & 29 & 90.6 & \\
\hline $1 b$ & Emergency LSCS & 3 & 18.8 & 3 & 9.4 & \\
\hline 2 & \multicolumn{5}{|c|}{ Antenatal Complications } & \\
\hline $2 \mathrm{a}$ & $\begin{array}{l}\text { Antenatal cervical } \\
\text { desiccation, } \\
\text { Edema, Laceration }\end{array}$ & 2 & 11.8 & 6 & 18.8 & \multirow{4}{*}{$\begin{array}{l}\text { On applying } \\
\text { Kruskal-Wallis } \\
\text { Test } \chi^{2} \text { is } 1.361 \\
\text { with } 1 \text { degree of } \\
\text { freedom and } \mathrm{P} \\
>0.05\end{array}$} \\
\hline $2 b$ & Prolonged Labor & 2 & 11.8 & 4 & 12.5 & \\
\hline $2 \mathrm{c}$ & PROM & 1 & 5.9 & 3 & 9.4 & \\
\hline $2 d$ & No complications & 11 & 64.7 & 15 & 46.9 & \\
\hline 3 & \multicolumn{5}{|c|}{ Postpartum complications } & \\
\hline $3 \mathrm{a}$ & $\mathrm{PPH}$ & 0 & 0 & 2 & 6.3 & \multirow{3}{*}{$\begin{array}{l}\text { On applying } \\
\text { Kruskal-Wallis } \\
\text { Test } \chi^{2} \text { is } 2.89 \\
\text { with } 1 \text { degree of } \\
\text { freedom and } P \\
>0.05\end{array}$} \\
\hline $3 b$ & IUD & 0 & 0 & 3 & 9.4 & \\
\hline $3 c$ & No complications & 17 & 100 & 27 & 84.4 & \\
\hline
\end{tabular}


IUD occurred in $3(9.1 \%)$ cases, neonatal death due to prematurity occurred in $1(9.4 \%)$ cases, NICU admissions in $9(28.1 \%$ ) unbooked cases (Table 2).
There was $\mathrm{H} / \mathrm{O}$ difficult delivery in $23(71.9 \%)$ unbooked women and H/O congenital anomaly in 2 (6.2\%) (Table 3).

Table 2: Neonatal Outcome.

\begin{tabular}{|c|c|c|c|c|c|c|}
\hline S. No & & $\begin{array}{l}\text { Booked } \\
(n=16)\end{array}$ & Percentage & $\begin{array}{l}\text { Unbooked } \\
(\mathrm{n}=32)\end{array}$ & Percentage & P value \\
\hline 1 & Mortality & & & & & \\
\hline $1 \mathrm{a}$ & IUD & 0 & 0 & 3 & 3.1 & \multirow{3}{*}{$\begin{array}{l}\text { On applying Kruskal- } \\
\text { Wallis Test } \chi^{2} \text { is } 2.264 \\
\text { with } 1 \text { degree of freedom } \\
\text { and } P>0.05\end{array}$} \\
\hline $1 b$ & $\begin{array}{l}\text { Neonatal } \\
\text { death }\end{array}$ & 0 & 0 & 1 & 9.4 & \\
\hline $1 \mathrm{c}$ & $\begin{array}{l}\text { No } \\
\text { complication }\end{array}$ & 17 & 100 & 28 & 87.5 & \\
\hline 2 & \multicolumn{5}{|c|}{ Gestational Age } & \\
\hline $2 \mathrm{a}$ & Preterm & 2 & 12.5 & 32 & 100 & \multirow{2}{*}{$\begin{array}{l}\text { On applying Mann- } \\
\text { Whitney U test } \mathrm{Z} \text { is } 6.221 \\
\text { and Asymptotic Sig is } \\
\mathrm{P}<0.05\end{array}$} \\
\hline $2 b$ & Term & 14 & 87.5 & 0 & 0 & \\
\hline 3 & \multicolumn{5}{|l|}{ Birth Weight } & \\
\hline $3 a$ & $\begin{array}{l}\text { Normal Birth } \\
\text { weight }\end{array}$ & 12 & 70.6 & 18 & 56.3 & \multirow{2}{*}{$\begin{array}{l}\text { On applying Mann- } \\
\text { Whitney U test } \mathrm{Z} \text { is } \\
0.97 \text { and Asymptotic Sig } \\
\text { is } \mathrm{P}>0.05\end{array}$} \\
\hline $3 b$ & $\begin{array}{l}\text { Low Birth } \\
\text { Weight }\end{array}$ & 5 & 29.4 & 14 & 43.8 & \\
\hline 4 & \multicolumn{5}{|c|}{ NICU admission } & \\
\hline $4 a$ & Yes & 2 & 11.8 & 9 & 28.1 & \multirow{2}{*}{$\begin{array}{l}\text { On applying Mann- } \\
\text { Whitney U test } \mathrm{Z} \text { is } 1.293 \\
\text { and Asymptotic Sig is } \mathrm{P} \\
>0.05\end{array}$} \\
\hline $4 b$ & No & 15 & 88.2 & 23 & 71.9 & \\
\hline
\end{tabular}

Table 3: Indications for LSCS and complications.

\begin{tabular}{|c|c|c|c|c|c|c|}
\hline S. No & & $\begin{array}{l}\text { Booked } \\
(n=16)\end{array}$ & Percentage & $\begin{array}{l}\text { Unbooked } \\
(n=32)\end{array}$ & Percentage & P value \\
\hline 1 & \multicolumn{6}{|c|}{ Duhrssen's required in vaginal delivery } \\
\hline 1a & Yes & 5 & 38.5 & 27 & 93.1 & \multirow{2}{*}{$\begin{array}{l}\text { On applying Mann- } \\
\text { Whitney U test } \mathrm{Z} \text { is } \\
3.798 \text { and } \\
\text { Asymptotic Sig is } \mathrm{P} \\
<0.05\end{array}$} \\
\hline $1 b$ & No & 8 & 61.5 & 2 & 6.9 & \\
\hline 2 & \multicolumn{6}{|c|}{ Indications for LSCS } \\
\hline $2 \mathrm{a}$ & Fetal Distress & 2 & 66.7 & 3 & 100 & \multirow{2}{*}{$\begin{array}{l}\text { On Chi Square Test } \\
\text { Pearson Chi square } \\
\text { is } \mathrm{P}>0.05 \text { with } 1 \\
\text { degree of freedom }\end{array}$} \\
\hline $2 b$ & $\begin{array}{l}\text { Intractable } \\
\text { Bleeding per } \\
\text { Vaginum }\end{array}$ & 1 & 33.3 & 0 & 0 & \\
\hline 3 & \multicolumn{6}{|c|}{ Labor Complications } \\
\hline $3 a$ & Prolonged Labor & 4 & 66.7 & 17 & 68.0 & \multirow{2}{*}{$\begin{array}{l}\text { On applying } \\
\text { Kruskal-Wallis Test } \\
\chi^{2} \text { is } 0.015 \text { with } 1\end{array}$} \\
\hline $3 b$ & $\begin{array}{l}\text { Post-partum } \\
\text { Hemorrhage }\end{array}$ & 1 & 16.7 & 5 & 20.0 & \\
\hline
\end{tabular}




\begin{tabular}{|c|c|c|c|c|c|c|}
\hline $3 c$ & Chorioamnionitis & 1 & 16.7 & 3 & 12.0 & $\begin{array}{l}\text { degree of freedom } \\
\text { and } P>0.05\end{array}$ \\
\hline 4 & \multicolumn{6}{|c|}{ Past obstetric history } \\
\hline $4 a$ & $\begin{array}{l}\text { Normal obstetric } \\
\text { history }\end{array}$ & 0 & 0 & 7 & 21.9 & \multirow{4}{*}{$\begin{array}{l}\text { On applying } \\
\text { Kruskal-Wallis Test } \\
\chi^{2} \text { is } 9.997 \text { with } 1 \\
\text { degree of freedom } \\
\text { and } \mathrm{P}<0.05\end{array}$} \\
\hline $4 b$ & $\begin{array}{l}\mathrm{H} / \mathrm{O} \text { prolonged } \\
\text { labor }\end{array}$ & 15 & 93.8 & 0 & 0 & \\
\hline $4 c$ & $\begin{array}{l}\mathrm{H} / \mathrm{O} \text { difficult } \\
\text { delivery }\end{array}$ & 1 & 6.2 & 23 & 71.9 & \\
\hline $4 d$ & $\begin{array}{l}\mathrm{H} / \mathrm{O} \text { congenital } \\
\text { anomaly }\end{array}$ & 0 & 0 & 2 & 6.2 & \\
\hline
\end{tabular}

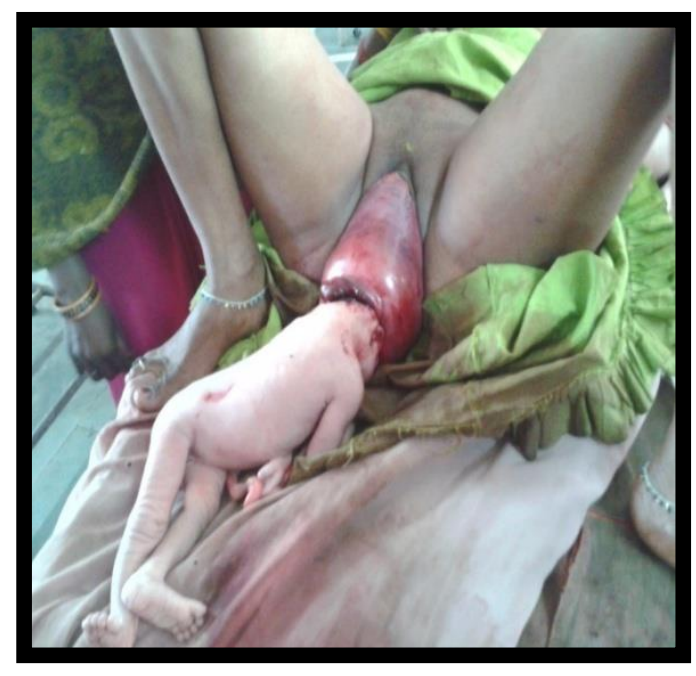

Figure 1: Arrested after-coming head of breech in a pregnancy with prolapse.

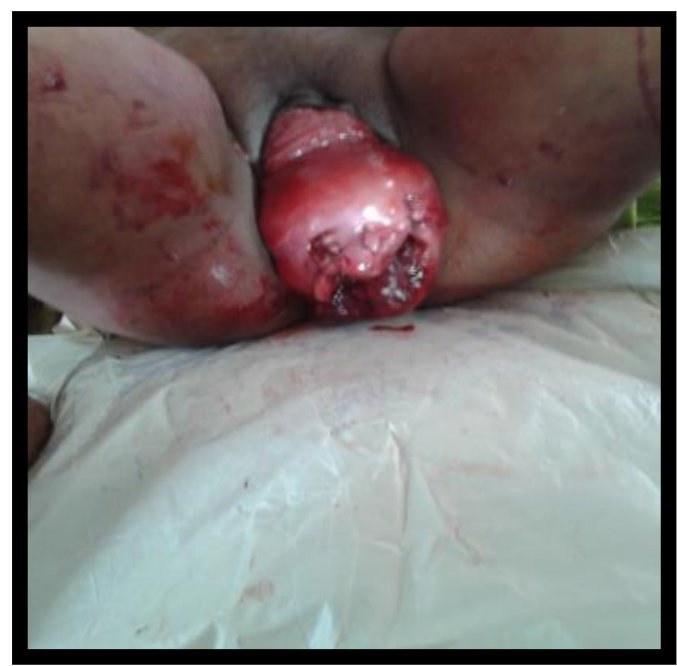

Figure 2: NVD by Duhrssen's incision.

Incidence of preterm labour and delivery, application of Duhrssen's incision in aiding vaginal delivery and h/o difficult delivery was statistically significant in unbooked women.

\section{DISCUSSION}

Many factors lead to the development of uterine prolapse and the most important cause is pregnancy associated with prolonged labor or difficult delivery which is a common scenario in India due to deliveries being conducted by untrained birth attendants. In many of the cases the pregnancy was superimposed on previous prolapse as shown in other studies also.

Prolapse can be aggravated by pregnancy, which is due to physiologic increases in cortisol and progesterone, which lead to a simultaneous softening and stretching of the pelvic tissues. An impairment of blood flow and cervical edema with subsequent tissue anoxia may contribute to increased incidence of abortion and preterm labor with prolapse. Klawans and Kanter reported a significant incidence of premature labor and perinatal loss for women with this complication. ${ }^{6}$ 34(70.8\%) cases presented with preterm labour in our study.

According to studies, cervical dystocia can occur due to a nonretractable edematous cervix, ${ }^{6}$ which was present in $23.5 \%$ cases in the study. Prolonged compression of cervix may lead to cervical tears and ischemic necrosis of bladder. Therefore, cervical incisions (Duhrssen's incisions) during vaginal deliveries are beneficial in fibrosed cervix.76.9\% of normal vaginal deliveries were conducted with the aid of Duhrssen's incision in our study thereby averting any complications, avoiding unnecessary cesarean section thus decreasing perinatal morbidity.

Management depends on the degree of prolapse and gestational age. The prolapsed uterus is usually managed by reducing the prolapse and bed rest in a slight Trendelenberg position. These methods have shown to protect the cervix from trauma and desiccation and decrease the incidence of preterm labour. ${ }^{(7)}$

In our study, $25 \%$ women who were booked \& had presented with preterm labour pains, were managed successfully with bed rest, vaginal packing \& tocolytics $\&$ could continue pregnancy till term. 
The mode of delivery remains a contentious issue in these cases. Conducting normal vaginal delivery under close supervision, with the aid of Duhrssen's incision can be a safe option. Literature review shows that most women are delivered by normal vaginal route. Elective cesarean section partially effective in preventing pelvic organ prolapse, cesarean delivery during active labour and vaginal delivery had similar effect on pelvic organ prolapse. ${ }^{8}$ Cesarean hysterectomy followed by vaginal cuff suspension to the periosteum overlying the sacral promontory could be an option in women who have completed their families and are suffering from pelvic organ prolapse complicating the third stage of pregnancy, especially in developing countries where access to health care is limited. ${ }^{9}$

Incarceration of a retroflexed gravid uterus should be considered to be the differential diagnosis in any woman who presents with voiding difficulty in late first or second trimester. Uterine prolapse is a risk factor for incarceration of a retroflexed uterus. ${ }^{10}$

\section{CONCLUSION}

Uterine prolapse in pregnancy though relatively uncommon is being increasingly noticed in Indian set-up due to high prevalence of risk factors.

Bed rest, vaginal packing and tocolysis in preterm labor help most women with cervical prolapse to continue their pregnancy till term with reduced risk of complications during labor and delivery.

However, management of uterine prolapse during labour is individualized depending on the severity of prolapse, gestational age, parity and patients preference.

Duhrssen's incision proved to be a simple and beneficial procedure in averting any complications and avoiding unnecessary cesarean section thus reducing perinatal morbidity

The trend towards adopting Cesarean section as an easy resort to avoid obstetric complications and undermining the relevance of obstetric maneuvers is on the increase among younger obstetricians. Implementation of such maneuvers like Duhrssen incision can go a long way in revival of dying art of operative obstetrics.

Therefore, Duhrssen incisionsare a safe and valid option for minimizing the complications during labour and averting the need for unnecessary caesarean section as illustrated in our study.

\section{REFERENCES}

1. Keettel WC. Prolapse of the uterus during pregnancy. Am J Obstet Gynecol 1941;42:121-126.

2. Kibel I. Pregnancy at term in prolapsed uterus. Am J Obstet Gynecol 1944;47:703-704.

3. Sawyer D, Frey K. Cervical prolapse during pregnancy. J Am Board Fam Pract. 1999;13(3).

4. Eddib A, Allaf MB, Lele A. Pregnancy in a woman with uterine procidentia: a case report. J Reprod Med 2010;55:67-70.

5. Daskalakis G, Lymberopoulos E, Anastasakis E, Kalmantis K, Athanasaki A, Manoli A, Antsaklis A. Uterine prolapse complicating pregnancy. Arch Gynecol Obstet 2007;276:391-392.

6. Klawans AH, Kanter AE. Prolapse of the uterus and pregnancy. Am J Obstet Gynecol. 1949;57:939-946.

7. Hill PS. Uterine prolapse complicating pregnancy. A case report. J Reprod Med 1984 Aug;29(8):631-3.

8. Sze EH, Sherard GB $3^{\text {rd }}$, Dolezal JM. Pregnancy, labour, delivery and pelvic organ prolapse. Obstet Gynecol. 2002;100:981-6.

9. Maydanli Mon, Ustun Y, Yalchin OT. Pelvic organ prolapse complicating third trimester of pregnancy. A case report. Gynecol Obstet Invest. 2006;61:1334.

10. Ozel B. Incarceration of a retroflexed gravid uterus from severe uterine prolapse. A case report. J Reprod Med. 2005;50:624-6.

DOI: $10.5455 / 2320-1770 . i j r \operatorname{cog} 20131219$

Cite this article as: Pandey K, Arya S, Pande S.

Pregnancy with uterine prolapse: Duhrssen's incision still valid in today's scenario? Int J Reprod Contracept Obstet Gynecol 2013;2:586-90. 